\title{
PENGGUNAAN METODE PROBLEM BASED LEARNING DENGAN PENDEKATAN SMART GROUP DISCUSSION - EXPERTUNTUK MENINGKATKAN KOMPETENSI MAHASISWA PROGRAM STUDI AKUNTANSI
}

\author{
Lely Kumalawati \\ Email: lelykumalawati@yahoo.com \\ Jurusan DIII Akuntansi Politeknik Negeri Madiun \\ Jl. Serayu 84 Madiun \\ Telp. (0351) 452970 Fax. (0351) 492960
}

\begin{abstract}
Abstrak
Tujuan penelitian ini adalah untuk mengetahui bagaimana metode problem based learning dengan pendekatan smart group discussion-expert yang dirancang oleh peneliti dapat meningkatkan kompetensi mahasiswa Jurusan Akuntansi. Alat ukur yang digunakan adalah evaluasi hasil belajar mahasiswa untuk semua mata kuliah yang diajarkan oleh peneliti dan evaluasi kinerja mengajar dosen. Tujuan jangka panjang penelitian ini adalah menemukan pendekatan baru dari metode problem based learning untuk dipatenkan di Politeknik Negeri Madiun. Pendekatan baru tersebut akan dijadikan dasar dan diusulkan untuk menetapkan rencana mutu pengembangan, evaluasi alternatif, evaluasi proses belajar mengajar, merekontruksi perangkat pembelajaran, dan mengembangkan bahan ajar. Penelitian ini dibagi dalam dua tahap, yaitu penelitian tahap pertama menggunakan siklus untuk penelitian tindakan kelas, dan penelitian tahap kedua hasil penelitian tindakan kelas akan diuji secara empiris dengan menetapkan variabel, hipotesis penelitian, dan diuji dengan teknik analisis regresi linear berganda.
\end{abstract}

Kata Kunci: Problem Based Learning, Smart Group Discussion-Expert

\section{Pendahuluan}

Metode pembelajaran yang kurang efektif dan efisien, menyebabkan tidak seimbangnya kemampuan kognitif, afektif dan psikomotorik. Pembelajaran yang monoton dari waktu ke waktu, pendidik yang bersifat otoriter dan kurang bersahabat dengan mahasiswa, merupakan contoh tidak seimbangnya kemampuan kognitif, afektif, dan psikomotorik sehingga mahasiswa merasa kurang antusias dan kurang minat belajar. Dosen sebagai tenaga pengajar dan pendidik seharusnya selalu meningkatkan kualitas profesionalismenya yaitu dengan cara memberikan kesempatan belajar kepada mahasiswa dengan melibatkan mahasiswa secara efektif dalam proses pembelajaran.

Keberhasilan pembelajaran dalam arti tercapainya standar kompetensi yang ditetapkan suatu program studi, sangat bergantung pada kemampuan dosen mengolah pembelajaran yang dapat menciptakan situasi yang memungkinkan mahasiswa belajar sehingga merupakan titik awal berhasilnya pembelajaran. Penelitian para ahli pendidikan menunjukkan bahwa pembelajaran akan berhasil bila mahasiswa berpartisipasi aktif dalam proses pembelajaran. Salah satunya adalah Pembelajaran Berbasis Masalah (PBM) dikembangkan dari pemikiran nilai-nilai demokrasi, belajar efektif perilaku kerja sama dan menghargai keanekaragaman di masyarakat.

PBM bermaksud untuk memberikan ruang gerak berpikir yang bebas kepada mahasiswa untuk mencari konsep dan menyelesaikan masalah yang terkait dengan materi yang disampaikan oleh dosen. Penggunaan metode PBM bagi mahasiswa tidak hanya sekedar menerima informasi dari dosen saja, karena dalam hal ini dosen sebagai motivator dan fasilitator yang mengarahkan mahasiswa agar terlibat secara aktif dalam seluruh proses pembelajaran dengan diawali pada masalah yang berkaitan dengan konsep yang dipelajari. Dosen harus dapat menciptakan lingkungan belajar sebagai suatu sistem sosial yang memiliki ciri proses demokrasi dan proses ilmiah. PBM merupakan jawaban terhadap 
praktik pembelajaran kompetensi serta merespon perkembangan dinamika sosial masyarakat.

PBM atau lebih sering dikenal sebagai Problem Based Learning (PBL) adalah metodologi pembelajaran dengan pendekatan berpusat pada peserta didik, fokus pada upaya membantu peserta didik memperoleh pengetahuan, keterampilan dan kemampuan berpikir kritis melalui proses belajar yang dinamis. PBL dikenalkan pertamakali pada tahun 1960-an, dimana siswa harus berurusan dengan kasus nyata, mendiagnosa masalah, melakukan penelitian dan mengusulkan solusi. Hal ini juga sering dikaitkan dengan "learning by doing","situated learning"atau" konstruktivisme sosial", yang dalam beberapa dekade terakhir dianggap oleh banyak pihak kalangan pendidikan sebagai langkah ke depan dalam mewujudkan sistem pendidikan yang progresif. Metode PBL saat ini telah dilaksanakan diseluruh dunia, termasuk Indonesia, diberbagai disiplin ilmu dari bisnis, teknik, IT, humaniora hingga ilmu hukum. PBL dalam berbagai bentuk juga telah diperkenalkan ditingkatan pendidikan dasar sampai dengan pendidikan tinggi, serta pelatihan kalangan profesional.

Barrow dan Kelsen (1993) meyatakan bahwa PBL merupakan pendekatan untuk menyesuaikan masalah atau memenuhi tantangan yang dihadapi dalam kehidupan dan karir $^{[1]}$. Studi Bold dan Felleti (1997) menemukan bukti bahwa PBL adalah pedagodi yang lebih efektif daripada metode ceramah konvensional ${ }^{[2]}$. Savery (2006) menyatakan bahwa pembelajaran berbasis masalah adalah pendekatan instruksional yang telah berhasil digunakan selama lebih dari tiga puluh tahun, dan terus mendapatkan pengakuan dari berbagai disiplin ilmu. PBL adalah pendekatan instruksional yang memberdayakan peserta didik untuk melakukan penelitian, mengintegrasikan teori dan praktik, dan menerapkan pengetahuan dan keterampilan untuk mengembangkan solusi yang layak untuk masalah yang diterapkan ${ }^{[3]}$.

Motivasi penelitian ini adalah penulis ingin mengetahui apakah metode PBL yang diterapkan di Politeknik Negeri Madiun khususnya Program Studi Komputerisasi Akuntansi berhasil dan terbukti meningkatkan kompetensi mahasiswa secara keseluruhan. Peneliti mengambil fokus metode pembelajaran PBL karena sering mengikuti berbagai kegiatan workshop PBL, pelatihan, dan studi banding ke Republic Polytechnic Singapore yang difasilitasi oleh DIKTI. Penulis sebelumnya pernah melakukan mini riset mandiri dan menulis artikel yang belum dipublikasikan tentang implementasi pengembangan PBL di Jurusan Akuntansi Politeknik Kediri, dengan pendekatan diskusi cerdas. Hasil yang diperoleh dari mini riset mandiri tersebut terbukti berhasil meningkatkan kompetensi mahasiswa untuk mata kuliah Akuntansi. Pendekatan yang digunakan pada saat itu diberi nama "Si CerdasExpert" (kepanjangan dari: Diskusi Cerdas yang menghasilkan para Ahli di bidang akuntansi). Hasil mini riset tersebut rencananya akan penulis patenkan, namun dalam perjalanannya sampai saat ini belum diusulkan dalam paten/hak kekayaan intelektual karena ada rasa kurang yakin dari penulis apakah metode tersebut dengan pendekatan diskusi cerdas dapat diterapkan di berbagai perguruan tinggi khususnya Program Studi Akuntansi. Penulis sebenarnya memiliki cara untuk meminimalisasi rasa kurang yakin dengan melakukan pengujian lanjutan, namun pengujian lanjutan tidak dilakukan karena terbentur dengan kebutuhan operasional penelitian yang tidak bisa dipenuhi. Latar belakang tersebut mendasari penulis ingin menguji metode PBL dengan pendekatan Smart Group Discussion-Expert berhasil meningkatkan kompetensi mahasiswa secara keseluruhan, dan diterapkan pada berbagai mata kuliah.Hasil penelitian ini jika terbukti berhasil meningkatkan kompetensi mahasiswa secara keseluruhan akan memberikan keyakinan yang memadai kepada penulis untuk diusulkan dalam paten/hak kekayaan intelektual, dan rencannya akan menjadikan slogan accountant expert untuk Jurusan Akuntansi di Politeknik Negeri Madiun. 


\section{Metode Penelitian}

Penelitian ini merupakan penelitian kualitatif. Penelitian kualitatif memerlukan justifikasi hasil penelitian ${ }^{[4]}$. Penelitian kualitatif dapat dilakukan dengan pendekatan etnografi (Berg, 2004; Moleong, 2002; Rasyid, 1998, dan Spradley, 1997) ${ }^{[5]}$. Penelitian ini merupakan penelitian tindakan kelas, dimana dosen berperan dalam kelas untuk mengatur jalannya kelas, dan mahasiswa mengikuti arahan dosen. Tahapan penelitian ini adalah dengan melakukan penelitian tindakan kelas yang terbagi dalam beberapa siklus, yaitu perencanaan, implementasi/pelaksanaan tindakan, pelaksanaan dan observasi pelaksanaan, umpan balik, dan refleksi ${ }^{[6]}$.

A. Siklus pertama (perencanaan) ${ }^{[7]}$

1) Yang dilakukan dosen:

a) Mengidentifikasi dan menganalisis materi sesuai kompetensi.

b) Penyusunan RPS, Silabus, dan Kontrak Kuliah.

c) Menyiapkan form evaluasi.

d) Membagi kelompok-kelompok belajar (smart group discussion - expert).

e) Menentukan permasalahan yang menjadi fokus bahasan pada setiap pertemuan.

2) Yang dilakukan mahasiswa

a) Mengeksplorasi masalah dan isu pembelajaran.

b) Mengklarifikasi istilah dan konsep yang tidak jelas pada teks masalah.

c) Menentukan masalah apa yang seharusnya dijelaskan.

B. Siklus kedua (implementasi/ pelaksanaan tindakan)

1) Yang dilakukan mahasiswa

a) Riset mandiri dan pembelajaran kolaboratif.

b) Analisis masalah: hasilkan ide sebanyak mungkin.

c) Susun ide-ide secara sistematis dan lakukan analisa mendalam.

C. Siklus ketiga (pelaksanaan dan observasi pelaksanaan)

1) Yang dilakukan dosen

a) Observasi pembelajaran.

b) Memberikan tanggapan.
2) Yang dilakukan mahasiswa

a) Formulasikan tujuan pembelajaran.

b) Formulasi tanggapan terhadap masalah dan menanggulagi rintangan pembelajaran.

c) Cari informasi lain dari sumber pembelajaran dan sandingkan.

d) Konsolidasi group tentang ide penyelesaian tanggapan terhadap masalah.

D. Siklus keempat (umpan balik)

1) Yang dilakukan dosen

a) Memberikan umpan balik

b) Memberikan solusi secara keseluruhan

2) Yang dilakukan mahasiswa

a) Merangkum secara menyeluruh dan menggunakan informasi baru yang telah dihasilkan.

b) Presentasi group dan kritik umpan balik dari dosen dan ringkasan dari isu-isu pembelajaran.

E. Siklus kelima (refleksi)

Yang dilakukan dosen dan mahasiswa: refleksi seluruh kegiatan pembelajaran, mengambil hal-hal positif dan selalu berpikir untuk menghasilkan sesuatu yang baru.

\section{Hasil dan Pembahasan}

Rangkaian kegiatan pada siklus pertama ada dua yaitu yang dilakukan dosen dan mahasiswa. Dosen pada siklus pertama melakukan hal-hal sebagai berikut yaitu;

a. Mengidentifikasi dan menganalisis materi sesuai kompetensi.

Mengidentifikasi dan menganalisis materi sesuai kompetensi dilakukan sebelum memberikan permasalahan kepada mahasiswa. Mengidentifikasi dan menganalisis materi sesuai kompetensi dilakukan untuk mencapai hasil yang diharapkan, yaitu permasalahan yang diberikan mampu menunjukkan tingkat kompetensi mahasiswa.

b. Penyusunan RPS, Silabus, dan Kontrak Kuliah.

Penyusunan RPS, silabus, dan kontrak kuliah merupakan media yang dapat dijadikan acuan bagi mahasiswa dalam 
setiap pertemuan. Penyusunan Penyusunan RPS, silabus, dan kontrak kuliah dilakukan sebelum awal semester dimulai.

c. Menyiapkan form evaluasi.

Form evaluasi digunakan untuk menilai hasil kerja mahasiswa. Form evaluasi berisi penilaian atas permasalahan yang telah diselesaikan oleh mahasiswa.

d. Membagi kelompok-kelompok belajar (smart group discussion-expert).

Koleompok-kelompok belajar smart group discussion - expert dibentuk sebelum permasalahan diberikan. Kelompok-kelompok ini dibentuk dengan tujuan agar permasalahan yang diberikan mampu diselesaikan dengan baik sesuai dengan rancangan metode penelitian.

e. Menentukan permasalahan yang menjadi fokus bahasan pada setiap pertemuan.

Permasalahan yang menjadi fokus bahasan pada setiap pertemuan diberikan sesuai dengan RPS, silabus, dan kontrak kuliah. Permasalahan didesain sedemikian rupa berbentuk kasus-kasus yang harus diselesaikan oleh kelompok-kelompok belajar smart group discussion-expert.

Pada siklus pertama yang dilakukan mahasiswa adalah:

a. Mengeksplorasi masalah dan isu pembelajaran.

Pada tahap ini mahasiswa sudah diberikan kasus sesuai dengan pertemuan pada saat itu. Kasus dibahas per kelompok-kelompok yang sudah dibentuk. Metode yang digunakan dalam kelompok belajar adalah smart group discussion - expert. Berdasarkan pengamatan dan bukti fisik hasil diskusi kelompok yaitu mayoritas mahasiswa mampu mengeksplorasi masalah dan isu pembelajaran, hal ini ditunjukkan dengan kemampuan masing-masing mahasiswa dalam pembahasan permasalahan di kelas.

b. Mengklarifikasi istilah dan konsep yang tidak jelas pada teks masalah.

Pada tahap mengklarifikasi istilah dan konsep yang tidak jelas pada teks masalah, kelompok-kelompok diskusi melakukan aktivitas diskusi interaktif antar teman, dengan tujuan untuk mendapatkan satu kesepahaman yaitu konsep yang tidak jelas pada teks masalah bisa dimengerti dengan baik. Teks masalah dapat dipahami dengan baik dilihat dari satu kesatuan pemahaman setiap kelompok dalam pembahasan di kelas.

c. Menentukan masalah apa yang seharusnya dijelaskan.

Pada tahap terakhir dari siklus pertama mahasiswa pada masing-masing kelompok sudah dapat menentukan fokus utama dari permasalahan yang akan dipecahkan. Permasalahan dieksplorasi pada masing-masing kelompok, selanjutnya dijawab dan dijelaskan oleh masing-masing kelompok.

Siklus

kedua (implementasi/pelaksanaan tidakan) oleh mahasiswa. Implementasi tindakan berkaitan dengan hal-hal teknis yang dilakukan mahasiswa untuk menjawab permasalahan, sehingga dari permasalahan yang telah diselesaikan dapat dinilai dan diputuskan kompeten atau tidak. Implementasi/pelaksanaan tindakan pada siklus kedua, yang dilakukan mahasiswa adalah:

a. Riset mandiri dan pembelajaran kolaboratif.

Riset mandiri dan pembelajaran kolaboratif bertujuan untuk memahami kedalaman permasalahan dan solusi yang diambil oleh masing-masing kelompok. Riset mandiri dilakukan pada setiap permasalahan yang diberikan dengan menggunakan smart group discussion - expert. Hasil dari riset mandiri penelitian ini adalah kedalaman menjelaskan permasalahan oleh masing-masing kelompok, yang ditunjukkan dengan pemahaman yang tepat sasaran oleh masing-masing anggota kelompok.

b. Analisis masalah: hasilkan ide sebanyak mungkin.

Analisis masalah dalam siklus ini, mahasiswa dituntut untuk menghasilkan ide sebanyak mungkin. Permasalahan yang ada diuraikan 
sedemikian rupa dengan berbagai alternatif untuk mengahasilkan ide yang lebih banyak. Ide tersebut akan digunakan sebagai justifikasi dari permasalahan yang dibahas oleh masing-masing kelompok. Hasil penelitian ini menunjukkan bahwa ide yang dihasilkan oleh masing-masing kelompok lebih dari lima untuk setiap permasalahan.

c. Susun ide-ide secara sistematis dan lakukan analisa mendalam.

Ide-ide yang telah dihasilkan disusun secara matematis untuk melakukan analisa lebih mendalam. Ide tersebut diurutkan sesuai kejadian permasalahan dan/atau urutan pemecahan masalah. Penelitian ini rata-rata ide yang dihasilkan diurutkan sesuai urutan pemecahan masalah untuk dilakukan analisa lebih mendalam.

Siklus ketiga dalam penelitian ini adalah pelaksanaan dan observasi pelaksanaan. Rangkaian kegiatan dalam siklus ketiga adalah dilakukan oleh dosen dan mahasiswa. Kegiatan yang dilakukan dosen diantaranya:

a. Observasi pembelajaran

Observasi pembelajaran yang dilakukan oleh dosen dalam penelitian ini adalah mengamati dan menilai berbagai aktivitas yang telah dilakukan oleh mahasiswa mulai dari siklus pertama. Observasi pebelajaran dilakukan sedetail mungkin agar justifikasi kompetensi dengan metode smart group discussion - expertyang tepat sasaran.

b. Memberikan tanggapan.

Memberikan tanggapan dalam penelitian ini dilakukan oleh dosen setelah observasi pembelajaran. Memberikan tanggapan merupakan feedback atas aktivitas dari siklus yang telah dilakukan oleh mahasiswa. Tanggapan diberikan oleh masingmasing kelompok yang terlibat dalam smart group discussion - expert.

Mahasiswa dalam siklus ke tiga melakukan hal-hal sebagai berikut:
a. Memformulasikan
tujuan
pembelajaran.

Tujuan pembelajaran yang ingin dicapai untuk masing-masing permasalahan yang dibahas ditetapkan di awal sebelum pembahasan materi dan sebelum smart group discussion expertdilakukan. Tujuan pembelajaran diformulasikan sedemikian rupa oleh mahasiswa untuk menilai diri sendiri, apakah smart group discussion - expert yang dirancang mampu memberikan penilaian kompetensi untuk masingmasing kelompok. Mahasiswa dalam penelitian ini menggali potensi diri dan memberikan penilaian pada diri sendiri dengan berkata jujur, dari permasalahan yang telah dibahas apakah mereka berhasil memahami dan menguasai permahasalan tersebut, sehingga layak disebut kompeten. Justifikasi mahasiswa dalam penelitian ini sebagai penunjang penilaian kompetensi oleh dosen.

b. Formulasi tanggapan terhadap masalah dan menanggulagi rintangan pembelajaran.

Penelitian ini formulasi tanggapan terhadap masalah dan menanggulagi rintangan pembelajaran dilakukan secara bertahap. Permasalahan yang ada dan sudah dilakukan pembahasan kemudian dievaluasi lebih dalam apakah ada rintangan dalam pembelajaran. Rintangan tersebut jika ada dicarikan alternatif tindakan dalam pembelajaran untuk pembahasan berikutnya. Penelitian ini rintangan pembelajaran hampir tidak terjadi.

c. Cari informasi lain dari sumber pembelajaran dan sandingkan.

Informasi lain dari sumber pembelajaran dapat disandingkan sebagai alternatif pilihan untuk mengatasi rintangan yang terjadi. Informasi lain juga dapat digunakan sebagai bahan pembanding hasil pembahasan permasalahan.

d. Konsolidasi group tentang ide penyelesaian tanggapan terhadap masalah.

Konsolidasi group dalam penelitian ini merupakan penyelesaian dan pengambilan keputusan terhadap permasalahan yang telah dibahas 
melalui smart group discussion expert. Kelompok diskusi mengambil suatu pembahasan yang telah menjadi untuk diformulasikan dalam penyelesaian dan memberikan tanggapan terhadap permasalahan. Penyelesaian dan memberikan tanggapan terhadap permasalahan ditulis sebagai hasil pembahasan materi yang diberikan.

Siklus keempat dalam penelitian ini adalah memberikan umpan balik. Umpan balik dalam penelitian ini dilakukan oleh dosen dan mahasiswa. Dosen dalam rangkaian siklus ini melakukan hal-hal sebagai berikut:

a. Memberikan umpan balik

Umpan balik yang diberikan dosen berupa tanggapan atas pelaksanaan aktivitas pembelajaran dengan metode smart group discussion - expert. Dosen juga memberikan analisa pembahasan yang tepat dan memberikan tanggapan atas pembahasan masing-masing kelompok diskusi.

b. Memberikan solusi secara keseluruhan Solusi secara keseluruhan dan mendalam dalam siklus ini diberikan oleh dosen sebagai bentuk kepastian jawaban yang tepat. Kelompok diskusi pada akhirnya memahami dan menguasai permasalahan yang telah dibahas.

Mahasiswa dalam siklus keempat melakukan hal-hal sebagai berikut:

a. Merangkum secara menyeluruh dan menggunakan informasi baru yang telah dihasilkan.

Pembahasan permasalahan yang telah disepakati oleh masing-masing kelompok diskusi dirangkum secara menyeluruh. Rangkuman tersebut merupakan informasi baru yang telah dihasilkan oleh kelompok diskusi dengan menggunakan smart group discussion - expert. Informasi baru kemudian dapat digunakan oleh seluruh mahasiswa.

b. Presentasi group dan kritik umpan balik dari dosen dan ringkasan dari isu-isu pembelajaran.

Rangkaian terakhir dalam siklus keempat adalah presentasi group.
Masing-masing kelompok diskusi melakukan presentasi atas hasil yang telah dicapai. Kelompok audiens dan dosen memberikan kritik dan saran, untuk diberikan tanggapan lebih lanjut. Keseluruhan kelompok diskusi setelah melakukan presentasi kemudian diarahkan oleh dosen untuk membuat ringkasan isu-isu pembelajaran, sehingga apa yang menjadi permasalah ditemukan solusinya secara mendalam dan menyeluruh.

Siklus kelima dari rangkaian kegiatan peneliaian ini adalah refleksi. Refleksi dilakukan oleh dosen dan mahasiswa. Dosen dan mahasiswa melakukan refleksi terhadap seluruh kegiatan pembelajaran, mengambil hal-hal positif dan selalu berpikir untuk menghasilkan sesuatu yang baru. Refleksi mencerminkan keterbukaan dalam berpikir, mengambil tindakan, eksplorasi masalah, dan menerima masukan dan saran dari pihak-pihak yang terkait, sehingga dapat dicapai informasi baru dan akurat yang dapat digunakan oleh seluruh mahasiswa.

Rangkaian siklus penelitian tindakan kelas dengan menggunakan metode smart group discussion - expert dapat diulang apabila ukuran kompetensi yang diharapkan belum dapat dicapai. Siklus dapat diulangulang sebagai alat bantu untuk menyatakan kompetensi mahasiswa.

Hasil penelitian secara keseluruhan menujukkan bahwa PBL yang dirancang dengan metodesmart group discussion expertmerupakan pendekatan yang dapat memberikan solusi efektif dalam meningkatkan kompetensi mahasiswa ${ }^{[8]}$. Hasil tersebut didukung dengan penelitian yang dilakukan oleh Rusmiyati (2007), Suci $(2008)^{[9]}, \quad$ Sumarsono $\quad(2006)^{[10]}$, Wafroturrohmah dan Suyatmini (2008) $)^{[11]}$, dan Wahyuningsih $(2005)^{[12]}$.

\section{Kesimpulan dan Saran}

A. Kesimpulan

Kesimpulan dalam penelitian ini adalah:

1) Metode pembelajaran dengan mengunakan metode smart group discussion - expert yang dirancang mampu memberikan keyakinan 
yang memadai terhadap kompetensi mahasiswa.

2) Penilaian kompetensi mahasiswa dilakukan melalui lima siklus. Siklus yang telah didesain harus dilakukan secara menyeluruh.

3) Masing-masing kelompok diskusi yang terlibat dalam pembelajaran dengan menggunakan metode smart group discussion - expert memberikan hasil yang memuaskan. Rata-rata kompetensi dapat dicapai dengan satu siklus menyeluruh.

B. Saran

Saran bagi peneliti selanjutnya dapat mengembangan model pembelajaran dengan metode smart group discussion expertdalam berbagai mata kuliah. Model pembelajaran dengan metode ini didesain dapat diterapkan pada berbagai bidang ilmu. Peneliti selajutnya juga dapat mengembangkan perangkat pembelajaran yang dapat menunjang metode ini.

\section{Daftar Pustaka}

[1] Barrows, H.S., dan Kelson, A.M. 1993. Problem Based Learning: A Total Approach to Education. Monograph Southern Illinois University School of Medicine. Springfield, Illinois.

[2] Boud, D., dan Feletti, G. 1997. The Challenge of Problem Based Learning (2nd ed). London: Kogan Page.

[3] Savery, J.R. 2006. Overview of Problem Based Learning: Definitions and Distinctions. Interdiscliplinary Journal of Problem Based Learning, 1 (1) 3.

[4] Berg, Bruce L. 2004. Qualitative Research Methods for Social Sciences $5^{\text {th }}$ ed. Boston: Pearson.

[5] Moleong, Lexy. 2002. Metode Penelitian Kualitatif. Bandung: Penerbit Rosdakarya.

[6] Rasyid, R. Eddy. 1998. Saling Peran (Interplay) antara Akuntansi dan Budaya Perusahaan: Penelitian Empiris dengan Metode InterpretifEtnografis. Jurnal Riset Akuntansi
Indonesia. Vol.1, N.1. Januari: 4366.

[7] Spradley, P. James. 1997. Metode Etnografi. Yogyakarta: PT Tiara Wacana.

[8] Rusmiyati, Arie. 2007. Pengembangan ModelPengajaran dengan Problem Based Instructionpada Pokok Bahasan Fluida untukMenumbuhkan Keterampilan Proses Sains.FMIPA UNNES.

[9] Suci, Ni Made. 2008. Penerapan Model Problem Based Learning untuk Meningkatkan Partisipasi dan Hasil Belajar Teori Akuntansi Mahasiswa Jurusan Ekonomi Undiksha. Jurnal Penelitian dan Pengembangan Pendidikan, Lembaga Pendidikan Undiksha Vol 2 (1): 74-86, April.

[10] Sumarsono, Gathot. 2006. Penerapan ProblemBased Instruction Sebagai UpayaMeningkatkan Hasil Belajar. FMIPA. UNNES.

[11] Wafroturrohmah dan Suyatmini. 2008. Penggunaan Metode PBL dalam Meningkatkan Kemampuan Belajar Mandiri Mahasiswa Jurusan Pendidikan Akuntansi pada Mata Kuliah Akuntansi Perpajakan. Varia Pendidikan, Vol. 20, No. 2, Desember.

[12] Wahyuningsih. 2005. Meningkatkan Logika BerpikirPokok Bahasan Suhu Melalui ModelPembelajaran Problem Based Instruction(PBI). FMIPA UNNES. 